\title{
IMPACT OF KRYPTON-85 BETA RADIATION ON AEROSOL PARTICLE FORMATION AND TRANSFORMATION*
}

\author{
V. Ulevičius ${ }^{\text {a }}$, D. Butkus ${ }^{\mathrm{b}}$, K. Plauškaitè ${ }^{\mathrm{a}}$, A. Girgždys ${ }^{\mathrm{b}}$, S. Byčenkienè ${ }^{\mathrm{a}}$, and \\ N. Špirkauskaitė ${ }^{a}$ \\ a Institute of Physics, Savanoriu 231, LT-02300 Vilnius, Lithuania \\ E-mail: ulevicv@ktl.mii.lt \\ ${ }^{\mathrm{b}}$ Vilnius Gediminas Technical University, Saulètekio 11, LT-10223 Vilnius, Lithuania
}

Received 6 October 2009; revised 19 November 2009; accepted 18 December 2009

\begin{abstract}
In this study the effect of the air ionization by ${ }^{85} \mathrm{Kr}$ beta radiation on the new particle formation and evolution of aerosol particle size distribution in the experimental chamber was investigated. During the experiments the interaction between air ionization and gas-to-particle conversion processes was distinctly observed. Results showed that the amplitude of the ionic current was dependent both on the chemical impurity concentration and the ionization source activity. Calculated values of parameters (growth and formation rates) of the particle nucleation process were larger when in the experimental chamber concentrations of $\mathrm{SO}_{2}$ and ${ }^{85} \mathrm{Kr}$ were higher. The growth rate values (42.1 and $45.3 \mathrm{~nm} / \mathrm{h}$ ) were by one order of magnitude higher than the environmental ones $(1.2-9.9 \mathrm{~nm} / \mathrm{h}$ at the Preila station, Lithuania). Experimental data showed that after injection of high $\mathrm{SO}_{2}$ and ${ }^{85} \mathrm{Kr}$ concentrations in the chamber during the $20 \mathrm{~min}$ interval nanometre-size particles created by nucleation were produced in large amounts. Thus, a larger amount of $\mathrm{SO}_{2}$ significantly influenced the formation of new particles. During the first $5 \mathrm{~min}$ the concentration of $10 \mathrm{~nm}$ particles increased by 3 orders of magnitude with the formation rate of $7.47 \mathrm{~cm}^{-3} \mathrm{~s}^{-1}$. The formation rate of $0.06 \mathrm{~cm}^{-3} \mathrm{~s}^{-1}$ in the experiment with the average ambient $\mathrm{SO}_{2}$ concentration $\left(2-3 \mu \mathrm{g} / \mathrm{m}^{3}\right)$ was analogous to the environmental one $\left(0.14 \mathrm{~cm}^{-3} \mathrm{~s}^{-1}\right)$. The coagulation sink $\left(\mathrm{CoagS}_{1,2,3}\right)$ was higher in the experiment with the ambient $\mathrm{SO}_{2}$ concentration and resulted in the lower concentration of particles. The smaller values of the coagulation sink at the higher concentration of $\mathrm{SO}_{2}$ gas have shown that these nano-particles in the air could persist for a longer time, probably in a stable size due to the ion charge.
\end{abstract}

Keywords: aerosol particles, experimental chamber, air ionization, nucleation characteristics, ${ }^{85} \mathrm{Kr}, \mathrm{SO}_{2}$

PACS: 92.20.Bk, 92.60.Mt, 68.55.AA

\section{Introduction}

During recent years the concerns about climate of the Earth change effects due to atmospheric aerosol particles have increased considerably. Nucleation mode of particles $(D<20 \mathrm{~nm})$ is highly effective in some geophysical processes $[1,2]$. The production of nanometresize particles by nucleation and their growth to detectable sizes have been investigated under various environmental conditions on regional and global scales: at remote $[3,4]$ and urban $[5,6]$ sites, in the boreal forests $[7,8]$, in the coastal zone $[9,10]$, in the marine environment $[11,12]$, etc. The specific conditions for the new particle formation might be formed at the location of nuclear facilities (nuclear power plant (NPP), nuclear

\footnotetext{
* This scientific publication of colleagues is dedicated to Dr. Arvydas Juozaitis (1959-1999), the initiator of research in this field at the Institute of Physics, Lithuania
}

fuel factory) as well. In these areas due to emission of radionuclides, mainly ${ }^{85} \mathrm{Kr}$ gas, into the ground level air, the enlarged ionization field is formed in which the deformation of the profiles of ion components in the air and structure of aerosol size distribution are observed $[13,14]$. The nuclear power plant of $1 \mathrm{MW}$ releases into the atmosphere about $2.5 \cdot 10^{21}$ atoms of ${ }^{85} \mathrm{Kr}$ per year, producing radioactivity of $5.1 \cdot 10^{12} \mathrm{~Bq}$ [15].

The ground level air undergoes constant ionization $\left(0.8 \cdot 10^{6}\right.$ ions $\left./\left(\mathrm{m}^{3} \mathrm{~s}\right)\right)$ due to ionizing radiation produced during the decay of natural radionuclides on the Earth's crust and by the penetrating component of cosmic rays. The calculated ion generation rate in the NPP jet was $1.0 \cdot 10^{6}$ ions $/\left(\mathrm{m}^{3} \mathrm{~s}\right)$, but in some cases under suitable meteorological conditions a ionization increase up to 1000 times in the vicinity of NPP can be expected $[13,16]$. Therefore, in the environment of operating nuclear objects potentially favourable conditions 
for aerosol particle formation events might be formed only over short time periods (from hours to a few days) or locally during the emergency situation of radionuclide emission.

However, in cases such as the Chernobyl accident when large soil areas $\left(>10^{4} \mathrm{~km}^{2}\right)$ with the high concentration of various life-time and type radiation radionuclides were polluted and more than 20 years passed, the increased ionization level in the air and aerosol size distribution deformation in these territories at present are observed $[17,18]$. The aerosol particle concentration and the size distribution were mainly dependent on a few factors such as activity of the ionization source and duration, amount of water vapour, gas impurities in the air, etc. $[14,19]$.

Laboratory experiments demonstrated that alpha decay of short-lived actinon $\left({ }^{219} \mathrm{Rn}\right.$, half-life of $\left.3.9 \mathrm{~s}\right)$ had a well pronounced influence on the aerosol particle nucleation and its evolution in time [20]. Repeated injection of ${ }^{219} \mathrm{Rn}$ resulted in formation of the bimodal aerosol particle size distribution. Madelaine et al. [20] considered coagulation of newly nucleated aerosol particles as a main process governing the aerosol particle growth toward larger diameters. Winklymayr et al. [21] studied radiolytically induced aerosol nucleation processes in a $\mathrm{N}_{2}-\mathrm{SO}_{2}-\mathrm{H}_{2} \mathrm{O}$ mixture using ${ }^{241} \mathrm{Am}$ as an ionization source. Aerosol particles with the modal diameter of about $2 \mathrm{~nm}$ were registered within $1 \mathrm{~s}$ after nucleation under dry air conditions. At higher water vapour and $\mathrm{SO}_{2}$ concentrations the aerosol particle concentration increased significantly and observed particles grew to a larger diameter.

The growth rate of aerosol particles is dependent on the type of chemical reactions involved in aerosol formation [22-24]. Chemical reactions can occur in the gas phase forming low vapour pressure products which condense on already existing aerosol particles or form new ones. Trace gases can also be adsorbed on the aerosol particle surface or absorbed within the airborne droplet. Theoretical expressions which give the dependence of the aerosol particle diameter growth rate, $\Delta D_{\mathrm{p}} / \Delta t$, on the particle diameter, $D_{\mathrm{p}}$, are different for each type of chemical reactions and are called growth laws.

McMurry and Wilson [22], Ulevičius et al. [23], Verheggen and Mozurkewich [24] have shown that, if gas phase chemical reactions lead to the particle growth by a low pressure vapour condensation, $\Delta D_{\mathrm{p}} / \Delta t$ is proportional to $D_{\mathrm{p}}^{0}$ in free molecule regime $\left(D_{\mathrm{p}} \ll\right.$ mean free path, $\lambda)$, to $D_{\mathrm{p}}^{-1}$ in continuum regime $\left(D_{\mathrm{p}} \gg\right.$ $\lambda)$ and to $D_{\mathrm{p}} \cdot f(\mathrm{Kn})$ in transition regime, where Knud- sen number $\mathrm{Kn}=2 \lambda / D_{\mathrm{p}}$. If chemical reactions leading to the aerosol particle growth take place on its surface, then $\Delta D_{\mathrm{p}} / \Delta t$ is proportional to $D_{\mathrm{p}}^{0}$ over the entire size range. This means that rates of chemical reactions on the particle surface are slower than collision rates between aerosol precursor gases and aerosol particles. When aerosol precursor gases dissolve in the droplet and react at a uniform rate throughout the droplet volume, $\Delta D_{\mathrm{p}} / \Delta t$ is proportional to $D_{\mathrm{p}}^{+1}$.

Although the influence of the radiative substances on the electrical properties of the atmosphere and transformation processes of aerosol particles is an indisputable fact, the majority of studies did not give information on the characteristics of the particle formation stages and evolution over time.

The aim of this study was to experimentally investigate the effect of the ionization by the ${ }^{85} \mathrm{Kr}$ beta radiation on the new particle formation in the air subject to chemical pollutant $\left(\mathrm{SO}_{2}\right)$ and the evolution processes of the aerosol particle size distribution.

\section{Methods}

\subsection{Experimental set-up}

The system of instruments for the experiment is schematically shown in Fig. 1. A plexiglass chamber $\left(0.6 \mathrm{~m}^{3}\right)$ was constructed at the Institute of Physics, Lithuania. It was equipped with a number of sensors for measurements of air temperature, relative humidity, pressure, and ${ }^{85} \mathrm{Kr}$ activity. The temperature was kept constant $\left(20 \pm 0.2^{\circ} \mathrm{C}\right)$ during each experiment using a mixture of water and alcohol, which was circulated through metallic radiators and stabilized by a thermostat. A temperature-controlled humidifier was used to establish a required level of relative humidity $(80 \pm 2 \%)$.

A flexible bag $\left(0.04 \mathrm{~m}^{3}\right)$ with ${ }^{85} \mathrm{Kr}$ concentration equivalent to $10^{10} \mathrm{~Bq} / \mathrm{m}^{3}$ radioactivity was used as a source of ${ }^{85} \mathrm{Kr}$ gas. The desirable concentration of ${ }^{85} \mathrm{Kr}$ in the experimental chamber was achieved by the dosage of ${ }^{85} \mathrm{Kr}$ gas entering the chamber from this bag through a particulate filter.

Prior to the experiment the plexiglass chamber was carefully brushed to avoid radioactive contamination. Once chamber was mechanically cleaned, the particle free air was flushed through this chamber at a flow rate of $60 \mathrm{l} / \mathrm{min}$. Experiments were started when the aerosol particle number concentration dropped below the desired "background" level $\left(0.01\right.$ particles $\left./ \mathrm{cm}^{3}\right)$. The ionization current in the experimental chamber was measured with an apparatus consisting of the capacitor 


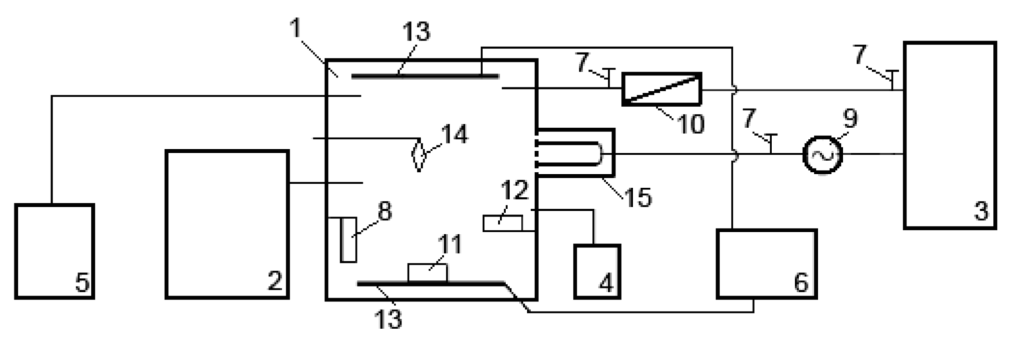

Fig. 1. Experimental set-up: chamber 1, aerosol spectrometer $2,{ }^{85} \mathrm{Kr}$ source 3, water evaporator 4, $\mathrm{SO}_{2}$ generator 5, thermostat 6 , valves 7 , beta counter 8 , pump 9 , filter 10 , heater 11 , pressure and humidity meters 12 , cooler 13 , thermocouple 14 , capacitor 15 .

and the picovoltmeter. The electrodes of the capacitor were cylindrical, their size and distance between them as well as the air flow rate were selected to have a laminar air flow through the capacitor.

The capacitor was installed outside the experimental chamber. To measure the concentrations of aero ions within the mobility band of $4 \cdot 10^{-6}-4 \cdot 10^{-4} \mathrm{~cm}^{2} /(\mathrm{V} \mathrm{s})$ the difference of potentials between the electrodes of the capacitor was changed from 5 to $500 \mathrm{~V}$. The current between the electrodes of the capacitor created by aero ions was equal to the current through the resistance.

Two experiments of the aerosol particle formation in ionization air by different activities of the ${ }^{85} \mathrm{Kr}$ $\left(1 \mathrm{~Bq} / \mathrm{m}^{3}, 4.6 \cdot 10^{6} \mathrm{~Bq} / \mathrm{m}^{3}\right)$ and $\mathrm{SO}_{2}$ concentrations $(2-$ $3 \mu \mathrm{g} / \mathrm{m}^{3}, 23 \mathrm{~g} / \mathrm{m}^{3}$ ) were performed.

\subsection{Aerosol size distribution and deposition in the chamber}

The aerosol particle number concentration and size distribution in the diameter range from 0.01 to $0.3 \mu \mathrm{m}$ were measured with an aerosol size spectrometer developed at the Institute of Physics, Lithuania [25, 26]. This spectrometer consists of a differential mobility analyzer (DMA) and a condensation particle counter (CPC).

The aerosol flow entered DMA through a bipolar charger ${ }^{239} \mathrm{Pu}$ which was used to establish the bipolar charge distribution on polydisperse aerosol particles. The inlet and outlet flow rates of DMA were the same and were equal to $21 / \mathrm{min}$. The particle free air flow in the differential mobility analyzer was equal to $201 / \mathrm{min}$ and was cycled through a high efficiency particulate (HEPA) filter by means of the two-way pump. The outlet flow of DMA carried charged monodisperse aerosol particles with the geometrical diameter $D_{\mathrm{p} i}$ which was dependent on the voltage $U_{i}$ applied to the centre rod of DMA, the particle free air flow rate $Q_{0}$ through DMA, the number $\gamma$ of elementary charges $e$ on the particle, and the geometry of the analyzer:

$$
D_{\mathrm{p} i}=\frac{2 \gamma e U_{i} l C_{c}}{3 \eta Q_{0} \ln \left(r_{2} / r_{1}\right)} .
$$

$C_{\mathrm{c}}$ is the Cunningham slip correction factor which is a function of the particle diameter, $\eta$ is the dynamic viscosity of the suspending air, $l$ is the distance along the DMA centre rod from aerosol entry to extraction, and $r_{1}$ and $r_{2}$ are the radii of the DMA centre rod and the housing, respectively.

The number of aerosol particles at the exit of DMA was registered with a mixing type condensation particle counter. Three quarters of the aerosol flow entered CPC through a saturation chamber thermostated at $20^{\circ} \mathrm{C}$. The remaining aerosol flow passed through a HEPA filter into a saturation chamber thermostated at $80^{\circ} \mathrm{C}$. The two airflows saturated in the butanol vapour were mixed in a supersaturation chamber. The degree of supersaturating was sufficient to grow all aerosol particles larger than $0.01 \mu \mathrm{m}$ to sizes compatible with the optical single particle counting. Grown aerosol particles were registered with an optical particle counter.

For the submicrometre particle size range measured, the effluent aerosol from DMA primarily consisted of charged particles with the geometric diameter $D_{\mathrm{p} i}$ carrying one elementary negative charge. At the same time, there were particles carrying two or more negative elementary charges. These had different geometric diameters, as seen from Eq. (1). Therefore, the ambient aerosol particle concentration and size distribution were calculated from the measurement data applying the data inversion routine previously developed by Whitby [27] and Hoppel [28].

Several processes may cause the aerosol particle size distribution change during the experiment. Deposition of particles on surfaces may also be an important factor, especially in a small chamber. Chen et al. [29] have shown that time change in the aerosol particle number concentration, $N(t)$, can be expressed as

$$
\frac{\mathrm{d} N(t)}{\mathrm{d} t}=-\beta N(t),
$$


Table 1. The constant $\beta$ calculated from the measurement data.

\begin{tabular}{lcccccc}
\hline Aerosol particle size, $\mu \mathrm{m}$ & 0.01 & 0.02 & 0.03 & 0.04 & 0.05 & 0.1 \\
$\beta, 10^{-5} \mathrm{~s}^{-1}$ & 56.0 & 23.0 & 17.0 & 11.0 & 5.0 & 4.0 \\
\hline
\end{tabular}

where $\beta$ is a constant which can be found experimentally:

$$
\beta=-\frac{\ln \left[\frac{N(t)}{N(0)}\right]}{t},
$$

$N(0)$ is the initial number concentration of the aerosol particle.

Aerosol particle size distributions were measured immediately after the injection of aerosol into the chamber and after 300 seconds. The constant $\beta$ calculated from the measurement data was size-dependent (Table 1). It decreased from $56 \cdot 10^{-5}$ to $4.0 \cdot 10^{-5} \mathrm{~s}^{-1}$ when the aerosol particle size increased from 0.01 to $0.1 \mu \mathrm{m}$.

These values of the constant $\beta$ were used in our data analysis.

\section{Theoretical approach}

A log-normal fitting of the aerosol particle size distribution was carried out. For both experiments the growth rate was calculated graphically from the contour plots (such as Figs. 3(b) and 4(b)), and, furthermore, the concentration of condensable vapour can be estimated from the growth rate. Since the exact identity of the condensable vapour is unknown, the concentrations were estimated by using transport values of sulphuric acid. Using given Eqs. (4)-(7), the characteristics of the new particle formation and growth during the investigation were calculated. The results of those calculations are presented in Table 2 . The observed particle formation and growth, the source rate of condensable material, and the changes of hygroscopic properties were analysed using three equations describing the rate of change of the vapour concentration, the aerosol particle number concentration, and the particle growth using the method by Dal Maso et al. [8]. Considering that condensable vapour molecules are of species $X$, the time dependence of vapour concentration $(C)$ can be expressed by [30]

$$
\frac{\mathrm{d} C}{\mathrm{~d} t}=Q-\mathrm{CS} \cdot C
$$

where $Q$ is the source rate of vapour and CS is its condensation sink rate on pre-existing aerosol. The time evolution of the aerosol number concentration $(N)$ in the size class $i$ can be presented by [31]

$$
\frac{\mathrm{d} N_{i}}{\mathrm{~d} t}=J_{i}-\operatorname{CoagS} \cdot N_{i},
$$

where $J_{i}$ is the formation rate of particles and CoagS is the coagulation sink rate for size $i$ particles. The growth rate can be expressed as [32]

$$
\frac{\mathrm{d} r}{\mathrm{~d} t}=\frac{m_{\mathrm{v}} \beta_{\mathrm{m}} D C}{r \rho}
$$

Here $r$ is the particle radius, $m_{\mathrm{v}}$ is the molecular mass of condensable vapour, $\beta_{\mathrm{m}}$ is the transitional correction factor for mass flux, $D$ is the diffusion coefficient, and $\rho$ is the particle density. Equation (6) can be integrated from $r_{0}$ to $r$ to obtain

$$
\begin{aligned}
C= & \left\{\rho \left[\frac{r^{2}-r_{0}^{2}}{2}+\left(\frac{4}{3 \alpha}-0.623\right) \lambda\left(r-r_{0}\right)\right.\right. \\
& \left.\left.+0.623 \lambda^{2} \ln \frac{\lambda+r}{\lambda+r_{0}}\right]\right\}\left(\Delta t D m_{\mathrm{v}}\right)^{-1} .
\end{aligned}
$$

Here $\alpha$ is the mass accommodation coefficient (i.e., sticking probability) and $\lambda$ is the mean free path. Directly from measurements of the aerosol size distribution changes and hygroscopicity properties, $\mathrm{d} r / \mathrm{d} t$, CS, CoagS, d $N_{10 \mathrm{~nm}} / \mathrm{d} t, N_{\text {nucleation mode, and the solu- }}$ ble fraction can be obtained. Detailed analysis of these equations can be found in Dal Maso et al. [8].

\section{Results and discussion}

Curve 2 in Fig. 2(a) shows that the ionic current increased by a factor of about 1.6 when a high concentration of the sulphur dioxide was injected into the chamber containing the ambient activity concentration of ${ }^{85} \mathrm{Kr}$ (about $1.0 \mathrm{~Bq} / \mathrm{m}^{3}$ ). A similar increase in the ionic current due to the injection of $\mathrm{SO}_{2}\left(2-3 \mu \mathrm{g} / \mathrm{m}^{3}\right)$ was observed in the chamber containing high activity concentration of ${ }^{85} \mathrm{Kr}\left(4.6 \cdot 10^{6} \mathrm{~Bq} / \mathrm{m}^{3}\right)$, (see 1 in Fig. 2(b)). The only difference was that the magnitude of the ionic current in the second case (2 in Fig. 2(b)) was about five times higher in comparison with the ionic current shown by 2 in Fig. 2(a). During the experiment the high concentrations of $\mathrm{SO}_{2}\left(23 \mathrm{~g} / \mathrm{m}^{3}\right.$, to verify $\mathrm{SO}_{2}$ impact on the new particle formation and growth) and ${ }^{85} \mathrm{Kr}$ 

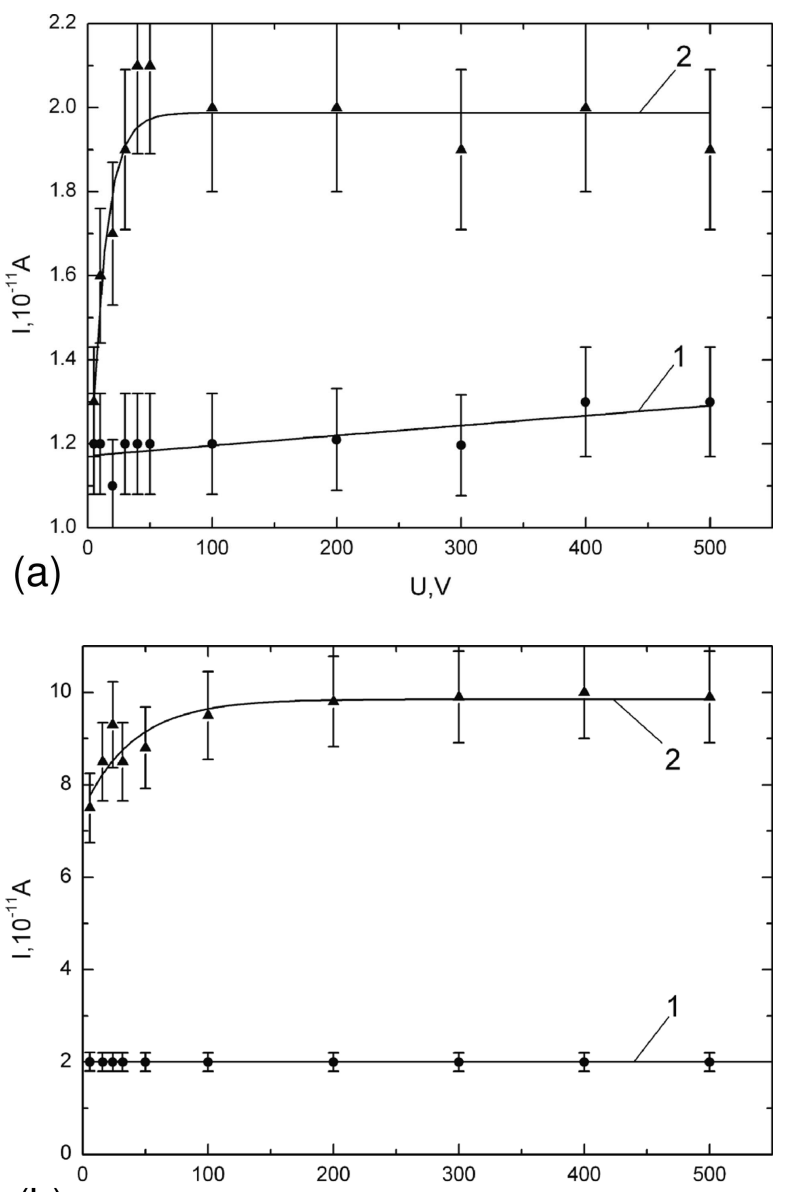

(b)

$\mathrm{U}, \mathrm{V}$

Fig. 2. Variation of the ionization current in the chamber: (a) $\mathrm{SO}_{2}$ $\left(2-3 \mu \mathrm{g} / \mathrm{m}^{3}\right),{ }^{85} \mathrm{Kr}\left(1.0 \mathrm{~Bq} / \mathrm{m}^{3}\right)(1)$ and $\mathrm{SO}_{2}\left(23 \pm 2.5 \mathrm{~g} / \mathrm{m}^{3}\right),{ }^{85} \mathrm{Kr}$ (1.0 Bq/ ${ }^{3}$ ) (2); (b) $\mathrm{SO}_{2}\left(2-3 \mu \mathrm{g} / \mathrm{m}^{3}\right),{ }^{85} \mathrm{Kr}(4.6 \pm 0.5) \cdot 10^{6} \mathrm{~Bq} / \mathrm{m}^{3}$

(1), $\mathrm{SO}_{2}\left(23 \pm 2.5 \mathrm{~g} / \mathrm{m}^{3}\right),{ }^{85} \mathrm{Kr}(4.6 \pm 0.5) \cdot 10^{6} \mathrm{~Bq} / \mathrm{m}^{3}$ (2).

activity $(4.6 \pm 0.5) \cdot 10^{6} \mathrm{~Bq} / \mathrm{m}^{3}$ in the chamber were injected.

The functional dependence of the ionic current on the voltage applied to the centre rod of the capacitor gives us information about mobility of aero ions generated in the experimental chamber. It is seen that the main increase in the ionic current was achieved when the voltage $U$ was increased up to $100 \mathrm{~V}$. This shows that light aero ions with the mobility above $2.0 \cdot 10^{-5} \mathrm{~cm}^{2} /(\mathrm{V} \mathrm{s})$ have been mostly responsible for the ionic current observed in our experiments. The measured slight increase in the ionic current after raising the voltage from 100 to $500 \mathrm{~V}$ demonstrates that aero ions with the mobility between $4.0 \cdot 10^{-6}$ and $2.0 \cdot 10^{-5} \mathrm{~cm}^{2} /(\mathrm{V} \mathrm{s})$ have also been present in the chamber, however, at much lower concentrations.

Air ionization promotes the oxidation of ambient gases as well as affects the surface properties of aerosol particles, therefore, it was expected that comparatively
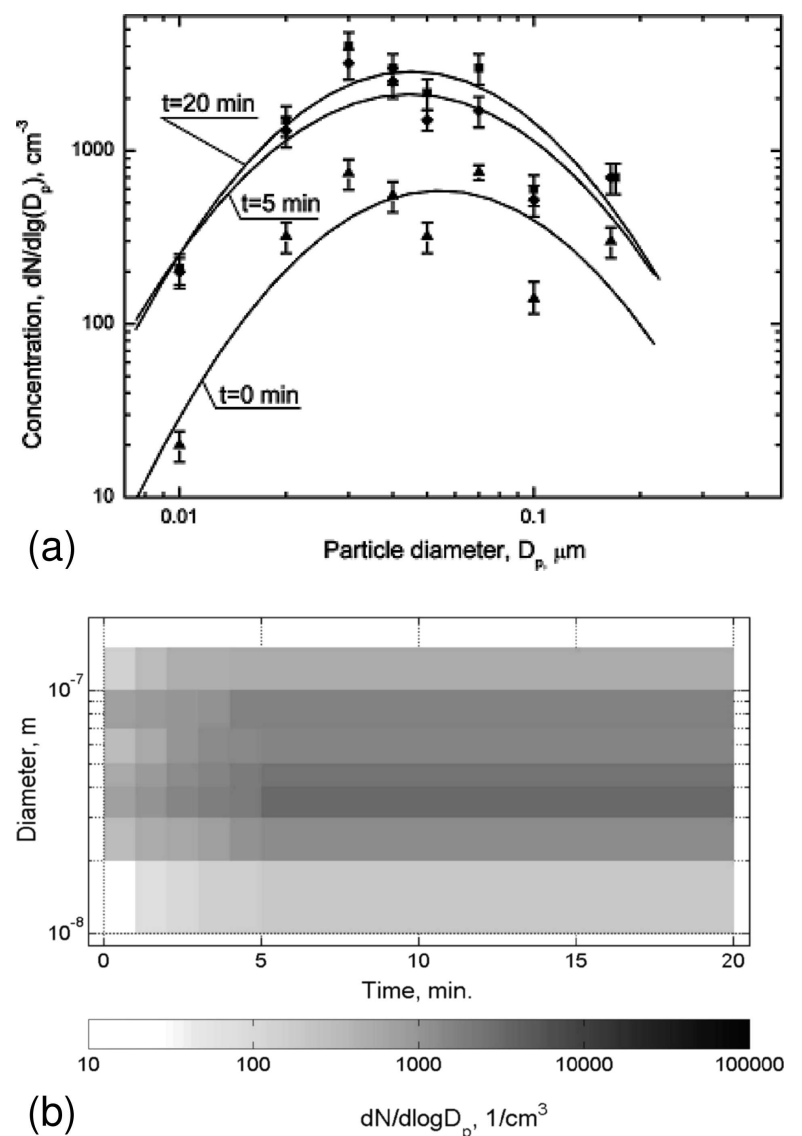

Fig. 3. (a) Size dependent variation of aerosol particle concentration and (b) time evolution of aerosol particle size distribution at $2-3 \mu \mathrm{g} / \mathrm{m}^{3}$ of $\mathrm{SO}_{2},(4.6 \pm 0.5) \cdot 10^{6} \mathrm{~Bq} / \mathrm{m}^{3}$ of ${ }^{85} \mathrm{Kr}$.

large aerosol particle formation and growth rates should be observed at high ${ }^{85} \mathrm{Kr}$ activity concentration. Data shown in Figs. 3 and 4 confirm this assumption.

In Fig. 3 it is shown that the injection of ${ }^{85} \mathrm{Kr}$ gas into the experimental chamber promotes the hygroscopical growth of aerosol particles and subsequently changes their size distribution. The models describing the hygroscopical growth of aerosol particles usually do not take into account the state of the air ionization. However, the data shown in Fig. 3(a,b) provides clear evidence that the hygroscopical growth factor is dependent on the air ionization.

As can be seen from Fig. 3(a,b), the concentration of aerosol particles of all sizes increases more than 10 times. Figure $4(\mathrm{a}, \mathrm{b})$ shows the effect of the ${ }^{85} \mathrm{Kr}$ beta radiation on the time change in the aerosol particle size distribution when ${ }^{85} \mathrm{Kr}$ and sulphur dioxide are present in the experimental chamber at high concentrations. There was a sudden increase in the aerosol number concentration after injecting ${ }^{85} \mathrm{Kr}$ into the experimental chamber. During $5 \mathrm{~min}$ the concentration of aerosol particles with the diameters of $10 \mathrm{~nm}$ increased by three 
Table 2. Calculated characteristics of nucleation events in both experimental cases.

\begin{tabular}{lccccc}
\hline Concentration & $\mathrm{GR}, \mathrm{nm} / \mathrm{h}$ & $J_{10}, \mathrm{~cm}^{-3} \mathrm{~s}^{-1}$ & $\mathrm{CoagS}_{1}, \mathrm{~s}^{-1}$ & $\mathrm{CoagS}_{2}, \mathrm{~s}^{-1}$ & $\mathrm{CoagS}_{3}, \mathrm{~s}^{-1}$ \\
\hline $\mathrm{SO}_{2} 2-3 \mu \mathrm{g} / \mathrm{m}^{3},{ }^{85} \mathrm{Kr}(4.6 \pm 0.5) \cdot 10^{6} \mathrm{~Bq} / \mathrm{m}^{3}$ & 42.1 & 0.06 & $3.20 \mathrm{E}-03$ & $1.10 \mathrm{E}-03$ & $6.00 \mathrm{E}-04$ \\
$\mathrm{SO}_{2}(23 \pm 2.5) \mathrm{g} / \mathrm{m}^{3},{ }^{85} \mathrm{Kr}(4.6 \pm 0.5) \cdot 10^{6} \mathrm{~Bq} / \mathrm{m}^{3}$ & 45.3 & 7.47 & $2.70 \mathrm{E}-03$ & $9.00 \mathrm{E}-04$ & $5.00 \mathrm{E}-04$ \\
\hline
\end{tabular}
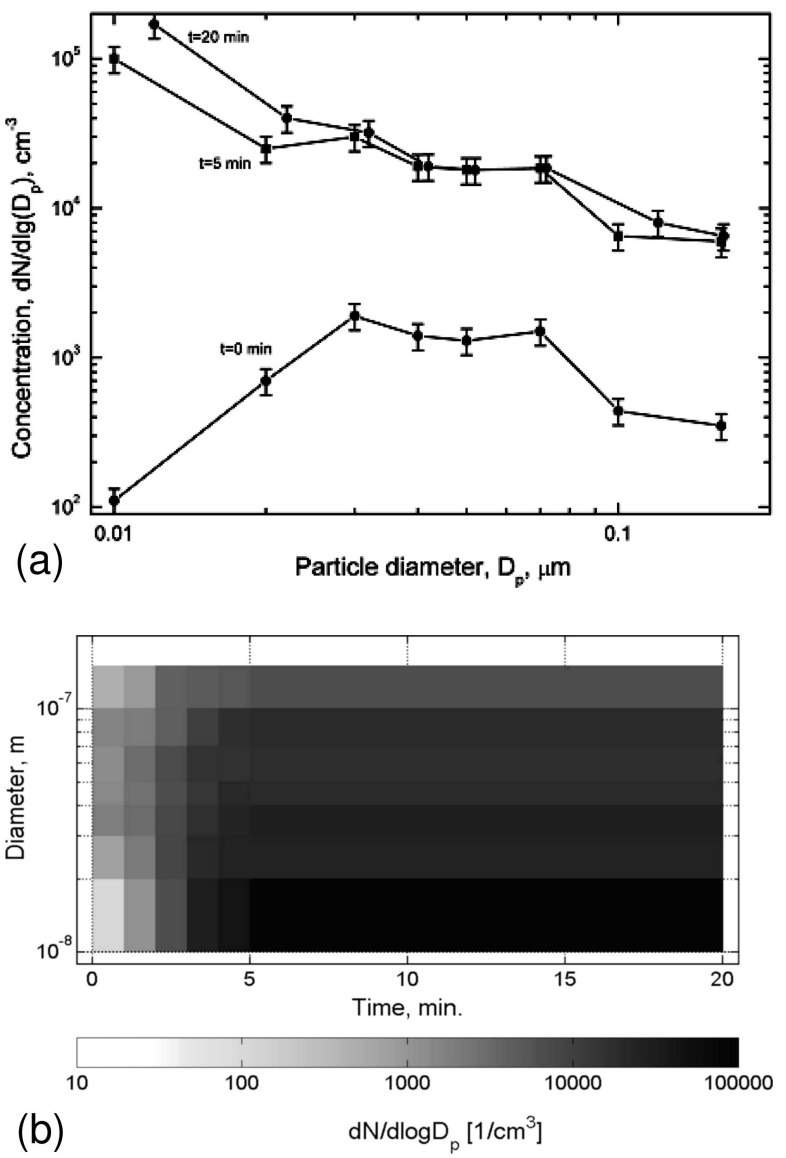

Fig. 4. (a) Size dependent variation of aerosol particle concentration and (b) time evolution of aerosol particle size distribution at $23 \pm 2.5 \mathrm{~g} / \mathrm{m}^{3}$ of $\mathrm{SO}_{2},(4.6 \pm 0.5) \cdot 10^{6} \mathrm{~Bq} / \mathrm{m}^{3}$ of ${ }^{85} \mathrm{Kr}$.

orders of magnitude. The concentration of aerosol particles larger than $30 \mathrm{~nm}$ increased more than 10 times. During the next 15 min the concentration of aerosol particles in the size range from 10 to $20 \mathrm{~nm}$ still increased due to the nucleation of new aerosol particles, while the number of aerosol particles larger than $30 \mathrm{~nm}$ remained stable. This means that the increase in the aerosol particle number concentration due to the gas-to-particle conversion in this size range is of the same magnitude as the chamber wall losses.

All calculated values of parameters of the particle nucleation processes were higher, while the concentrations of $\mathrm{SO}_{2}$ and ${ }^{85} \mathrm{Kr}$ in the experimental chamber were higher, except the coagulation sink $\left(\mathrm{CoagS}_{1,2,3}\right)$. It was higher in the experiment with the ambient $\mathrm{SO}_{2}$ concentration and resulted in the lower concentration of the particles. The largest difference between processes of the aerosol particle formation in both experiments concerns the formation rate $\left(J_{10}\right)$ which considerably influences the concentration of $10 \mathrm{~nm}$ particles (Fig. 4(b)), when $\mathrm{SO}_{2}$ of high concentration is injected into the chamber with high ionization and $80 \%$ relative humidity. During the first $5 \mathrm{~min}$ the concentration of $10 \mathrm{~nm}$ particles increased by 3 orders of magnitude with the formation rate of $7.47 \mathrm{~cm}^{-3} \mathrm{~s}^{-1}$. In the study [19] using ${ }^{239} \mathrm{Pu}$ as an ionization source, two maxima of the new particle formation, at respectively $40-60 \%$ and $80-95 \%$ relative humidity, were observed. The value of the formation rate $\left(0.06 \mathrm{~cm}^{-3} \mathrm{~s}^{-1}\right)$ in our experiment with the average ambient $\mathrm{SO}_{2}$ concentration $\left(2-3 \mu \mathrm{g} / \mathrm{m}^{3}\right)$ was analogous to the environmental ones, i. e. the median formation rate at the Preila coastal site was $0.14 \mathrm{~cm}^{-3} \mathrm{~s}^{-1}$ [9]. However, the difference of the growth rate (GR) values during both experiments was not very significant (Table 2) and the notable increase of the concentration of larger particles was not observed. The growth rate values were much higher than the environmental ones, e. g. the growth rates at the Preila environmental pollution research station varied between 1.2 and $9.9 \mathrm{~nm} / \mathrm{h}$ (median was $3.9 \mathrm{~nm} / \mathrm{h}$ [9]. Such high values of the growth rate clearly revealed the influence on the new particle formation.

\section{Conclusions}

During the experiments the interaction between air ionization and gas-to-particle conversion processes was distinctly observed. Our results showed that the amplitude of the ionic current was dependent both on the chemical impurity concentration and the ionization source activity in the experimental chamber. Calculated values of parameters (growth and formation rates) of the particle nucleation process were larger when concentrations of $\mathrm{SO}_{2}$ and ${ }^{85} \mathrm{Kr}$ were higher. Experimental data showed that after injection of high $\mathrm{SO}_{2}$ and ${ }^{85} \mathrm{Kr}$ concentrations in the chamber during the $20 \mathrm{~min}$ interval nanometre-size particles (as most dangerous for human health) created by nucleation were produced in large amounts. The difference of growth rate values during experiments was not very significant and the notable increase of the concentration of larger particles was not observed. The growth rate values (42.1 
and $45.3 \mathrm{~nm} / \mathrm{h}$ ) were by one order of magnitude higher than the environmental ones $(1.2-9.9 \mathrm{~nm} / \mathrm{h}$ at the Preila station). The larger amount of $\mathrm{SO}_{2}$ significantly influenced the formation of new aerosol particles. The largest formation rate $\left(J_{10}\right)$ of aerosol particles was detected at high ionization, $80 \%$ relative humidity, and high $\mathrm{SO}_{2}$ concentration in the experimental chamber. In this case during the first $5 \mathrm{~min}$ the concentration of $10 \mathrm{~nm}$ particles increased by 3 orders of magnitude with the formation rate of $7.47 \mathrm{~cm}^{-3} \mathrm{~s}^{-1}$. The value of the formation rate of aerosol particles was $0.06 \mathrm{~cm}^{-3} \mathrm{~s}^{-1}$ in the experiment with the average ambient $\mathrm{SO}_{2}$ concentration $\left(2-3 \mu \mathrm{g} / \mathrm{m}^{3}\right)$ and it was analogous to the environmental one $\left(0.14 \mathrm{~cm}^{-3} \mathrm{~s}^{-1}\right)$. A larger value of the coagulation sink in the experiment with the $\mathrm{SO}_{2}$ concentration of the ambient level and the lower concentration of the formed particles was observed. The smaller values of the coagulation sink at the higher concentration of $\mathrm{SO}_{2}$ gas have shown that these nano-particles in the air could persist for a longer time, probably in a stable size due to the ion charge. Although the processes occurring in the experimental chamber may differ significantly from those observed in the natural environment, however, during the nuclear accident after penetration of large amounts of radionuclides involving also $\mathrm{Kr}$ isotopes and various gaseous chemical compounds, such processes are possible in the atmosphere as well.

\section{References}

[1] M. Kulmala , H. Vehkamaki, T. Petaja, M. Dal Maso, A. Lauri, V. Kerminen, W. Birmilli, and P. McMurry, Formation and growth rates of ultrafine atmospheric particles, A review of observations, J. Aerosol Sci. 35, 143-176 (2004).

[2] A. Lushnikov and M. Kulmala, A new flux-matching theory of particle charging, Europhys. J. D 29, 345-355 (2004).

[3] A. Kristensson, M. Dal Maso, E. Swietlicki, T. Hussein, J. Zhou, V.M. Kerminen, and M. Kulmala, Characterization of new particle formation events at a background site in Southern Sweden: relation to air mass history, Tellus B 60, 330-344 (2008).

[4] N.S. Holmes, A review of particle formation events and growth in the atmosphere in the various environments and discussion of mechanistic implications, Atmos. Environ. 41, 2183-2201 (2007).

[5] A. Hamed, J. Joutsensaari, S. Mikkonen, L. Sogacheva, M. Dal Maso, M. Kulmala, F. Cavalli, S. Fuzzi, M.C. Facchini, S. Decesari, M. Mircea, K.E.J. Lehtinen, and A. Laaksonen, Nucleation and growth of new particles in Po Valley, Italy, Atmos. Chem. Phys. 7, 355-376 (2007).
[6] M. Dal Maso, L. Sogacheva, P.P. Aalto, I. Riipinen, M. Komppula, P. Tunved, L. Korhonen, V. SuurUski, A. Hirsikko, T. Kurtén, V.-M. Kerminen, H. Lihavainen, Y. Viisanen, H.-C. Hansson, and M. Kulmala, Aerosol size distribution measurements at four Nordic field stations: identification, analysis and trajectory analysis of new particle formation bursts, Tellus B 59, 350-361 (2007).

[7] B. Bonn, M. Kulmala, I. Riipinen, S.L. Sihto, and T.M. Ruuskanen, How biogenic terpenes govern the correlation between sulfuric acid concentrations and new particle formation, J. Geophys. Res. 113, D11209 (2008).

[8] M. Dal Maso, M. Kulmala, I. Riipinen, R. Wagner, T. Hussein, P.P. Aalto, and K.E.J. Lehtinen, Formation and growth of fresh atmospheric aerosols: eight years of aerosol size distribution data from SMEAR II, Hyytiälä, Finland, Boreal Environ. Res. 10(5), 323336 (2005).

[9] K. Plauškaitè, R. Kazlauskaitè, J. Andriejauskienė, and V. Ulevičius, Parameterization of new particle formation and growth at the Preila station, Lithuanian J. Phys. 45, 139-147 (2005).

[10] V. Ulevičius, G. Mordas, and K. Plauškaite, Nucleation events at the Preila environmental research station, Environ. Chem. Phys. 24, 38-44 (2002).

[11] Ü. Kikas, A. Reinart, A. Pugatshova, E. Tamm, and V. Ulevičius, Microphysical, chemical and optical aerosol properties in the Baltic Sea region, Atmos. Res. 90, 211-222 (2008).

[12] A.P. Hyvärinen, M. Komppula, C. Engler, N. Kivekäs, V.M. Kerminen, M. Dal Maso, Y. Viisanen, and H. Lihavainen, Atmospheric new particle formation at Utö, Baltic Sea 2003-2005, Tellus 60B, 345-352 (2008).

[13] R. Jasiulionis, Ionizing radiation doses in the environment of the Ignalina NPP, Lithuanian J. Phys. 42, 6164 (2002).

[14] V. Smirnov, Deformation of ionic, gaseous and aerosol compositions in the air by the radioactive matter pollution, Collections IEM 19(152), 45-60 (1992) [in Russian].

[15] B. Styro and D. Butkus, Geophysical Problems of Krypton-85 in the Atmosphere (Mokslas, Vilnius, Lithuania, 1988) [in Russian].

[16] R. Jasiulionis, R. Krenevičius, J.L. Morkeliūnas, and J. Jablonskas, Air ionization in the NPP jet, in: Annual Report 1992 (Institute of Physics, Vilnius, Lithuania, 1992) pp. 74-77.

[17] V. Matuolis and P. Polukordas, An evaluation of the atmosphere ionization state on the territory of the Lithuanian SSR in May-June 1986, Atmos. Phys. 14, 28-37 (1989) [in Lithuanian].

[18] V. Smirnov, Electrical characteristics of the air in the zone of the Chernobyl NPP accident, Collections IEM 19(152), 111-122 (1992) [in Russian]. 
[19] V. Kornienko and V. Smirnov, Investigation of stimulated gas-particle conversion in the atmosphere, Collections IEM 51(142), 99-109 (1990) [in Russian].

[20] G.J. Madelaine, M.L. Perrin, and A. Renoux, Formation and evolution of ultrafine particles produced by radiolysis and photolysis, J. Geophys. Res. 85, 74717474 (1980).

[21] V. Winklymayr, M. Ramamurthi, R. Strydom, and P.K. Hopke, Size distribution measurements of ultrafine aerosols, $d_{p}>1.8 \mathrm{~nm}$, formed by radiolysis in a diameter measurement analyzer aerosol charger, Aerosol Sci. Technol. 13, 394-398 (1990).

[22] P.H. McMurry and J.C. Wilson, Growth laws for the formation of secondary ambient aerosols: Implications for chemical conversion mechanisms, Atmos. Environ. 16, 121-134 (1982).

[23] V. Ulevičius, S. Trakumas, and A. Girgždys, Aerosol size distribution transformation in fog, Atmos. Environ. 28, 795-800 (1994).

[24] B. Verheggen and M. Mozurkewich, Determination of the nucleation rate from observation of a $\mathrm{SO}_{2}$ induced atmospheric nucleation event, J. Geophys. Res. 107, 4123 (2002).

[25] A. Juozaitis, S. Trakumas, R. Girgždienè, A. Girgždys, D. Šopauskienè, and V. Ulevičius, Investigations of gas-to-particle conversion in the atmosphere, Atmos. Res. 41, 183-201 (1996).
[26] A. Juozaitis, V. Ulevičius, A. Girgždys, and K. Willeke, Differentiation of hydrophobic from hydrophilic submicrometer aerosol particles, Aerosol Sci. Technol. 18, 202-212 (1993).

[27] K.T. Whitby, W.E. Clark, V.A. Marple, G.M. Sverdrup, G.J. Sem, K. Willeke, B.Y.H. Liu, and D.Y.H. Pui, Characterization of California aerosols - 1 . Size distributions of freeway aerosol, Atmos. Environ. 9, 463-482 (1975).

[28] W.A. Hoppel, Determination of the aerosol size distribution from the mobility distribution of the charged fraction of aerosols, J. Aerosol Sci. 9, 41-54 (1978).

[29] B.T. Chen, H.C. Yeh, and Y.S. Cheng, Evaluation of an environmental reaction chamber, Aerosol Sci. Technol. 17, 9-24 (1992).

[30] M. Kulmala, A. Toivonen, J.M. Mäkelä, and A. Laaksonen, Analysis and growth of the nucleation mode particles observed in Boreal forest, Tellus 50B, 449-462 (1998).

[31] M. Kulmala, M. Dal Maso, J.M. Mäkelä, L. Pirjola, M. Väkevä, P.P. Aalto, P. Miikkulainen, K. Hämeri, and C. O'Dowd, On the formation, growth and composition of nucleation mode particles, Tellus 53B, 479490 (2001).

[32] M. Kulmala, Nucleation as an Aerosol Physical Problem, $\mathrm{PhD}$ thesis, University of Helsinki, Department of Physics (Helsinki, Finland, 1988).

\title{
${ }^{85} \mathrm{Kr}$ BETA SPINDULIUOTĖS İTAKA AEROZOLIO DALELIŲ FORMAVIMUISI IR TRANSFORMACIJOMS
}

\author{
V. Ulevičius ${ }^{a}$, D. Butkus ${ }^{b}$, K. Plauškaite ${ }^{a}$, A. Girgždys ${ }^{b}$, S. Byčenkienè ${ }^{a}$, N. Špirkauskaite ${ }^{a}$ \\ ${ }^{a}$ Fizikos institutas, Vilnius, Lietuva \\ ${ }^{\mathrm{b}}$ Vilniaus Gedimino technikos universitetas, Vilnius, Lietuva
}

\section{Santrauka}

Eksperimentineje kameroje tirtas ${ }^{85} \mathrm{Kr}$ beta spinduliuotès jonizacijos, sukeltos ore, poveikis aerozolio daleliu susidarymui ir ju dydžiu spektrui. Aerozolio dalelių formavimuisi poveikį turejjo ir jonizacijos laipsnis, ir cheminès priemaišos $\left(\mathrm{SO}_{2}\right)$ koncentracija. Ivedus i kamerą dideles $\mathrm{SO}_{2}$ ir ${ }^{85} \mathrm{Kr}$ koncentracijas, per pirmąsias 20 min. aerozolio dalelių koncentracijos padidejo net keliomis eilèmis. Ypač sparčiai aerozolio dalelių koncentracija padidèjo padidinus kameroje $\mathrm{SO}_{2}$ koncentraciją. Esant didesnei $\mathrm{SO}_{2}$ koncentracijai, greičiau formavosi ir aerozolio dalelès, o formavimosi grei- tis skyrèsi eile nuo stebimo gamtineje aplinkoje (Preilos stotyje), atitinkamai 42,1-45,3 ir 1,2-9,9 nm/h. Aerozolio dalelių formavimosi greičiai eksperimento metu, esant padidintai jonizacijai ir $\mathrm{SO}_{2}$ koncentracijai $\left(2-3 \mu \mathrm{g} / \mathrm{m}^{3}\right)$ kaip fonineje stotyje ore, buvo panašūs, atitinkamai 0,06 ir $0,14 \mathrm{~cm}^{-3} \mathrm{~s}^{-1}$. Aerozolio dalelių koaguliacinis nuotèkis buvo didesnis eksperimente, $\mathrm{kai} \mathrm{SO}_{2}$ koncentracija buvo lygi gamtinei. Kai buvo didelès $\mathrm{SO}_{2}$ ir ${ }^{85} \mathrm{Kr}$ koncentracijos, aerozolio dalelių koaguliacinis nuotėkis buvo mažesnis, kas rodo, kad nanometrinių dydžių dalelès lèčiau pasišalino iš oro dèl koaguliacijos. 